\title{
Introduction
}

\section{Special Issue: A Sociology of Competition}

Hartmann, Eva; Kjær, Poul F.

\section{Document Version}

Accepted author manuscript

\section{Published in:}

Distinktion

DOI:

10.1080/1600910X.2015.1088877

Publication date:

2015

\section{License}

Unspecified

Citation for published version (APA):

Hartmann, E., \& Kjær, P. F. (2015). Introduction: Special Issue: A Sociology of Competition. Distinktion, 16(2), 141-145. https://doi.org/10.1080/1600910X.2015.1088877

Link to publication in CBS Research Portal

\section{General rights}

Copyright and moral rights for the publications made accessible in the public portal are retained by the authors and/or other copyright owners and it is a condition of accessing publications that users recognise and abide by the legal requirements associated with these rights.

Take down policy

If you believe that this document breaches copyright please contact us (research.lib@cbs.dk) providing details, and we will remove access to the work immediately and investigate your claim. 


\section{Introduction: Special Issue: A Sociology of Competition} Eva Hartmann and Poul F. Kjaer Journal article (Post print version)

This is an Accepted Manuscript of an article published by Taylor \& Francis Group in Distinktion: Scandinavian Journal of Social Theory on 16/10/2015, available online: http://www.tandfonline.com/10.1080/1600910X.2015.1088877

Uploaded to Research@CBS: November 2015

Available at: http://research.cbs.dk/da/publications/introduction\%280bf4991bfa81-4029-b714-297237dd3e94\%29.html 
Special Issue: A Sociology of Competition

Eva Hartmann and Poul F. Kjaer ${ }^{1}$

Introduction

Competition has become a catchword which divides the world. Some present it as panacea that will solve the current economic crisis. Much in line with Adam Smith, competition is seen as the most effective means to prevent producers from overpricing their products and from delivering bad quality. This take on competition differs diametrically from the view which fears that strong competition will trigger a destructive race to the bottom, to the detriment of the whole society. Despite these fundamental differences, what both positions have in common is the assumption that competition has a major impact on society. In their seminal book on EU competition law, Michelle Cini and Lee McGowan identify competition policy as the most important organizing principle in the capitalist world' (Cini and McGowan, 1998: 2).

In the light of the importance assigned to competition, it comes as something of a surprise that competition is not a major topic within sociology. This special issue intends to contribute to the overcoming of this lacuna by outlining key dimensions of a sociology of competition. Such an account of competition is much more than just a subcategory of economic sociology; it rather explores all the different forms of competition in the sphere of economics, politics, sport, knowledge, beauty, fashion, art and love, to name but a few areas where competition has gained momentum.

Fortunately, this intellectual endeavour does not have to start from scratch but can benefit from the reasoning on competition which was prevalent in the sociology of the end of the $19^{\text {th }}$ and the beginning of the $20^{\text {th }}$ century. Accordingly, the contributions to this special issue draw on scholars such as Georg Simmel, Emile Durkheim and Karl Marx, as well as Talcott Parsons, Franz Neumann, Antonio Gramsci, Karl Polanyi and more recent sociological accounts of competition developed by Pierre Bourdieu, Michel Foucault and Niklas Luhmann. The overall idea is to cover a broad range of different sociological accounts of competition with a view to providing a better understanding of how competition structures society.

\footnotetext{
1 This contribution has been developed with support from the European Research Council within the project 'Institutional Transformation in European Political Economy - A Socio-legal Approach (ITEPE-312331).
} 
The contributions also aim to cover a broad range in methodological terms. Some analyses in this issue examine changes in the scholarly discussion on competition over the last two centuries. Other studies take the dissemination of these arguments into account by analysing changes in the dictionaries' definition of competition. Another contribution examines the World Bank's training manuals, which are used in capacity building workshops. Last but not least, the concept of competition and its modification is studied through the lens of European case law.

The issue starts with a historical sociological study examining the role of competition in the evolution of European statehood. This study essentially turns upside down the argument of critics of neoliberalism, who fear that competition will undermine the state. Poul F. Kjaer argues that competition was vital for the constitution of the modern state. The emerging modern European states used institutionalised forms of competition to weaken rival claims to public power and authority of, for example, the church, the guilds and the nobility. Hence, this account of competition considers competition as a governing tool, as the stick which accompanies the carrot of sharing privileges with rival groups in order to obtain their support for the states claim to supremacy. It provides an interesting middle way between two contrasting accounts of the evolution of statehood. The first account focuses on the state-centredness of society, and relates this specificity of modern society to a successful sub-subsumption of non-state processes under the state. The second state-theoretical account considers, conversely, the emergence of the state with its own relative autonomy and bureaucratic structure as a result of the further differentiation of society, underpinning a self-reflexive self-limitation of the state. Interrelating these two positions, Kjaer points out a paradoxical double movement by which the state with the help of the instrument of competition expands into society by the very fact of being increasingly differentiated from society. A key element in this constitution of self-constraining modern public power is the legal form. Legal categories impose limits on modern political power, while at the same time establishing its general nature, since only generalizable norms are recognised as law under modern conditions. By way of this process of abstraction, which is never geared towards specific persons but rather towards persons in the abstract, the state-based political system differentiates itself from and simultaneously reconnects itself with the rest of society. This dissociation-reassociation through law is not limited to the market but applies to all segments of society, Kjaer argues. The way in which the state secures its power has, however, continuously changed over the last two centuries, Kjaer points out in his distinction between 
corporatism, neo-corporatism and governance. Three types of intermediary institutions which all are characterised by different ways through which rival claims to public power vis-à-vis the state has been either advanced or curtailed under modern conditions and the advancement or rejection of competition has therefore been a central point of orientation within all three types of intermediary institutions.

Major changes are also at the core of Bob Jessop's study, which warns us not to overstate the role of competition as the organising principle of society. Economic exchange does not have to be acted out through profit-oriented price mediated competition, Jessop argues. It only plays a paramount role in a competitive financialised economy and in a full-fledged finance-dominated capitalist economy, hence only in two out of six (ideal)types of economy which Jessop outlines in his historical analysis. The organising principles of the other four ideal-types were reciprocity, re-distribution, rulebased quantification, or mercantilism. Drawing on Polanyi's insight that a market economy requires a market society, Jessop outlines how these different economies are related to different forms of state. However, Jessop prefers to speak of state projects in order to avoid a monolithic understanding of the state and to highlight the various struggles within the state and its bureaucratic apparatus over the appropriate mode of governing society. With the emergence of the competitive financialised economy and, subsequently, a full-fledged finance-dominated capitalist economy competition, state projects have increasingly become organised around the idea of competitiveness as the strategic "dispositif", to use a notion coined by Foucault. Competition is no longer restricted to the routine activities of firms in a stable environment, but has become a means to advance a Schumpeterian creative destruction with a view to establishing a new type of market state/society complex. The key words for this transformation are the competitive state or entrepreneurial state, justifying the reorganisation of public bureaucracy in the name of new public management.

The extension of competition beyond the economic realm also is at the centre of Tobias Werron's sociological account of competition. His reconstruction of the modification of the concept of competition, in the vein of Reinhart Koselleck's conceptual history, illustrates a gradual extension of the application of competition over the last two centuries; this is well documented by the modifications of the definition of competition published in dictionaries. Against this background and in the vein of Georg Simmel, Werron develops a generic notion of competition which can be applied to the 
different social realms and is hence no longer restricted to the economy. This account describes competition as an interaction between two competitors competing for the scarce attention of the audience. Hence, competition is always already an intersubjective relation organised in the shape of a triad. The more abstract the audience, the more generalised is the interaction between the competitors. The audience can be the stock market, or the consumers as an imagined community, or the sovereign with two political parties competing for people's votes. In this interaction, each competitor emphasises what distinguishes him or her from the other with a view to outcompeting the other. Paradoxically, this differentiation ends in uniformity, as Werron argues convincingly. Competitors observe each other in their competition for the scarce attention of the audience and by doing so they both start to imitate what they consider to be legitimate behaviour. By interrelating this line of reasoning with sociological institutionalism and its account of the interaction between legitimacy and isomorphism, Werron broadens Simmel's account of competition. The Human Development Index (HDI) is a case in point. HDI is based on generic standards comparing the performance of countries in the field of economy, health and education. Hence, it provides a tertiary comparationis standards as a common reference for countries competing for the prestige of being recognised as a modern, well-functioning state. A similar mechanism of comparison by way of a common reference point is at work in the global rankings of higher education institutions.

Ngai-Ling Sum has further developed this analysis of interrelation through comparison by studying the Global Competitiveness Index of the World Economic Forum. Sum uses this example to illustrate the heuristic value of an account of Cultural Political Economy which marries Marx, Gramsci and Foucault in order to better grasp the symbolic and imaginary dimensions which a critique of political economy should take into account. This account calls for attention to the selectivity of the discourses, and thus goes beyond a liberal discourse analysis which essentially assumes that the different discourses compete on an equal footing. On more empirical grounds, Sum's contribution takes a global perspective. It outlines how the World Bank and the Asian Development Bank promote global competition and catch-up competitiveness by relating them to poverty reduction strategies. Her analysis identifies an important shift in development policy which is no longer informed by Friedrich List's idea of catch-up development justifying temporary protection of national market against stronger competitors. The new dispositif draws on a Ricardian emphasis on comparative advantage, and advises the 
countries of the South to find their comparative advantage. Similar to Werron, though drawing on a different theoretical perspective, Ling's analysis points out the co-existence of diversity and uniformity. The search for competitive advantage should be organised against the background of common competition standards which define the appropriate level of transparency, non-discrimination and procedures. Her study shows that the failure to establish such standards in a centralised way in the context of the World Trade Organisation (WTO) has paved the way for a more decentralised strategy which promotes this ideational framework by way of loans but also best practices and capacitybuilding workshops for individuals which are organised by the World Bank or Asian Bank. This account of competition points out a new institutionalisation of what Foucault has dubbed governmentality (Foucault, 2008). The ideational framing of ordoliberalism with its emphasis on the state's vital role in ensuring competition is no longer restricted to the nation state but has gained a global scope. Sum highlights the subject constituting effect of this discourse concretised in workshop programmes and manuals. Competition and its underlying non-discriminatory provisions is here considered a formal organising principle of society, a mode of abstraction which essentially remains an eidos with major consequences for society (Müller-Armack, 1978: 327, Foucault, 2008: 120). Accordingly the principle of competition is not restricted to economic policy. It also includes what Rüstow calls "vitalpolitik", which aims to activate the individual with a view to securing the vitality of an entrepreneurial society (Rüstows, 1957).

The subject constituting effect of competition law is also at the heart of Christiane Mossin's contribution, which focuses on European Union law and particularly the rulings of the European Court of Justice. Mossing argues that a logic of competition can only gain in importance when unfolding as a constellation of heterogeneous logics and in connection with spontaneous human activities. Part of this unfolding process is a tension between an ideal order and a presumed order which is considered to exist prior to and independently of the law in question. Paradoxically, the new order co-constructs the presumed order it intends to modify. In this regard, law is transformative and conservative at the same time. Mossin's case study examines the complex dynamic as well as the interconnectivity of different logics in the sphere of the EU's fundamental right to free movement of people. The non-discrimination in not directly market-related areas, such as social benefits, has become vital for enhancing European mobility of workers. We could relate this complex constellation interrelating different logics to an insight Adam Smith already pointed out when he wrote: "it appears evidently from 
experience that a man is of all sorts of luggage the most difficult to be transported." (Smith, 2007 [1901]: 67) Mossin's study of seminal rulings of the ECJ points out how the integration of different logics went hand in hand with a gradual extension of the notion of workers. This transformation brings to the fore the logic of belonging, which can no longer be reduced to a real link to the labour market. It is rather a potential link by which EU migrants become integrated into their EU host countries on a non-discriminatory basis. Mossin calls this as-if link mystical, since it is not based on a real link but rather a fetish, a belonging projected into the future. Along these lines we have outlined elsewhere the contested nature of this emerging type of European social bonds which are established through the transformation of the worker into a European citizen (Hartmann, 2015).

The transformation of social bonds through competition is also at the centre of the final contribution. Eva Hartmann focuses on professions and their regulations, such as fixed fees, which recalls what Polanyi called a 'regulated economy' (Polanyi, 1968 [1944]: 30). In this sense, professions stand in opposition to the market economy. At the same time, they play a vital role in ensuring social cohesion and in backing up the state, as different accounts of sociology of professions underline. Hartmann's point of departure is the fact that professions have become subsumed under European nondiscrimination provisions and competition law. A number of observers have interpreted this move as an indicator of the end of this specific type of occupational group. In contrast to this position, Hartmann underlines the importance of competition for the Europeanising the professional complex with major consequences for society. Integrating a Durkheimian and Weberian notion of professions into a Gramscian theory of hegemony and transferring this perspective to the European level her study points to professions as a major enabler of European hegemony. However, it also outlines the limits of the ECJ in advancing the transformation of the professional complex and highlights a complex interaction between the Court, the EU, the Member States and the professions in the establishment of standards of equivalence. Furthermore, the empirical findings confirm the thesis according to which not all market exchanges are based on competition. Reciprocity continues being a vital exchange mechanism in the emerging European professional market. However, the modern form of exchange through reciprocity requires, similar to competition, common standards of comparison which make different professionals comparable and hence exchangeable. This mode of abstraction creates a fetish of commonality, an economic imaginary paving the way for a 
European imagined community. It enables integration but also masks relations of power and exploitation since it treats subjects as if they were on an equal footing.

We thus hope to contribute with this special issue to a sociology of competition which draw our attention to the complex processes engaged in the establishment of competition and standards of comparison which, once completed, disappears from the limelight into the shadow of society's backstage.

\section{References}

Cini, Michelle, And LeE McGowan. (1998) Competition Policy in the European Union. Basingstoke: Palgrave Macmillan.

Foucault, Michel. (2008) The Birth of Biopolitics, Lectures at the College de France 1978-79. Houndsmill: Palgrave Macmilan.

Hartmann, Eva. (2015) European Social Policy: Social Cohesion through Competition? In The Evolution of Intermediary Institutions in Europe From Corporatism to Governance, edited by Eva Hartmann and Poul F. Kjaer. Basingstoke: Palgrave Macmillan.

MÜller-ArmaCK, Alfred. (1978) The Social Market Economy as an Economic and Social Order Review of Social Economy 36:325-33.

POLANYI, KARL. (1968 [1944]) The Great Transformation: The Political and Economic Origins of Our Time. Boston, MA,: Beacon Press.

Rüstows, Alexander. (1957) Vitalpolitik gegen Vermassung. In Masse und Demokratie, edited by Albert Hunold. Erlenbach-Zürich: Rentsch.

SMith, AdAM. (2007 [1901]) An inquiry into the nature and cause of the wealth of nations. An electronic classics series publication. 